\title{
15 TAMING ROGUE CLERGY AND CHURCHES: GOD, SCANDALS, GOVERNMENT AND RELIGIOUS REGULATION IN KENYA
}

\section{Damaris Seleina Parsitau ${ }^{1}$}

\section{INTRODUCTION}

In Kenya, as is the case in many parts of the African continent, religion is both a social and political force. It is therefore not surprising that the religious industry has been booming for the last three decades, with little or no regulations of its activities. In the recent past, Kenyans have witnessed an increasingly high number of religious scandals committed by men and women of God, who are supposedly also keepers of morality and ethics. While rogue clergy are increasingly becoming a panacea to the Kenyan public, they have also attracted significant debates and discourses, with loud calls for stricter regulation of these clergy and their churches. However, relatively little academic attention has been devoted to these phenomena. ${ }^{2}$ Based on recent ethnographic research, as well as social analysis and observations of the Kenyan social and religious scene, this chapter highlights and demonstrates through case studies some of the recent scandals involving Kenya's clergy from the Pentecostal churches, with a view to providing a moral, ethical and social critique of the Kenyan social, political and religious scene.

This chapter explores these tensions by highlighting the challenges this phenomenon presents to the public and the Kenyan government, caught between freedoms of expression and attempts to regulate religious organisations and rogue clergy in Kenya. Further, this inquiry attempts to answer the following questions: How can the government tame rogue clergy in an extremely contested social, political and religious sphere like Kenya? Who will hold rogue clergy to account and what is being done? What are the tensions inherent in regulating rogue clergy and political power? The chapter is organised into several sections. Firstly, I discuss the social and religious background in Kenya,

1 Damaris Seleina Parsitau is the Director of the Institute of Women Gender and Development Studies and a Senior Lecturer at the Department of Philosophy, History and Religious Studies at Egerton University, Kenya. She is also an Associate Fellow and a Visiting Research Fellow at UNISA, South Africa. This chapter is written courtesy of generous research grants from the Nagel Institute in the USA.

2 For an in-depth analysis of one of these rogue clergy, arguably the biggest of them all, Prophet David Owuor, see Parsitau DS. 2016. "Prophets, power, authority and the Kenyan state: Prophet David Owuor of the National Repentance and Holiness Ministry", in Coertzen P, Green MC and Hansen L (eds). Religious Freedom and Religious Pluralism in Africa: Prospects and Limitations. Stellenbosch: African Sun Media, 233-255. 


\section{Religion, Hate Speech, Diversity and Equality}

as well as the proliferation of the Neo-Pentecostal churches, some of which have been involved in scandal. This overview is followed by case studies of rogue clergy and their churches, as well as government attempts to regulate the churches. Lastly, I offer a social and moral critique of these churches and their clergy, as well as their gullible members.

\section{WHEN GOD BECAME KENYAN: KENYA'S SOCIAL AND RELIGIOUS LANDSCAPE: SETTING THE CONTEXT}

Kenya is a nation with a rich religio-cultural diversity. With its population of 38.6 million people, the country is an embodiment of historical, cultural, ethnic, religious, social, political and linguistic affinities and diversities. Indeed, its religious landscape is quite complex, dynamic and diverse, including African Indigenous Religion (AIR), various strands of Christianity and Islam as well as smaller groups of practitioners of Hinduism, Buddhism, Baha'i and Judaism, among other religions. Demographically, Kenya is predominantly Christian. The Kenyan Population and Housing Census of 2009 revealed that Christians constitute about 31.8 million of Kenya's 38.6 million people. What this essentially means is that about $82.6 \%$ of the population in Kenya is Christian, constituting a significant majority compared with other faiths. ${ }^{3}$ It is further estimated that 4.3 million of the population are Muslims. ${ }^{4}$ The non-religious population is small but nevertheless significant. Accurate statistics for minority faiths are difficult to access and are largely a matter of conjecture. However, the major religious traditions in Kenya are Christianity and Islam, both of which have been influenced by indigenous African religious traditions.

All these religious traditions, to use religion scholar Afe Adogame's words, "have mutually enhanced and transformed each other in a highly competitive context." 5 Besides, they serve as significant sources through which many Kenyans seek to understand their complex reality and existence. For these reasons, religious ideas and worldviews continue to shape the ways in which Kenyans explain, predict, and control the events and life circumstances that surround them. It can correctly be argued that religion and spirituality have served as a significant source through which many Kenyans seek to understand both their complex reality and existence and which serve as a panacea for their various existential problems of day-to-day living. Moreover, Kenya is not the

3 Kenyan National Bureau of Statistics. 2010. Kenya: 2009 Population and Housing Census Highlights. Nairobi: KNBS, 2.

4 Statistics for Kenyan Muslims have been deeply politicised and highly contested with some Muslim groups suggesting that the population is anywhere between 10 to 30 percent of the population. This claim is however not supported by demographic data, as was evident in the 2009 Population Census.

5 Adogame A. 2010. "How God became a Nigerian: Religious Impulse and the Unfolding of a Nation", Journal of Contemporary African Studies 28(4):479-498. 
only religious country in Africa, as indicated by report from the Pew Forum on Religion and Public Life. ${ }^{6}$

Given these statistics, it is not surprising that religious actors and institutions have become powerful forces in shaping social, spiritual and political developments on much of the African continent. At the same time, new religious movements such as the Pentecostal and charismatic churches have recently proliferated in Sub-Saharan Africa in recent decades and have completely altered the social and religious landscape of the country.

\section{THE PROLIFERATION OF PENTECOSTAL CHRISTIANITY IN KENYA: SETTING THE CONTEXT}

The Pentecostal and charismatic Christian movements exploded onto the Kenyan social and religious scene and have steadily grown from the 1980s, establishing hundreds of churches all over the country. Since the 1990s, these have become perhaps the fastest growing spiritual movements in Kenya today. Similarly, they have attracted thousands of followers, mainly educated youth, women and other social groups. At present, Kenyan Neo-Pentecostalism represents the most visible evidence of religious renewal, as attested by its social and public prominence and constitutes the fastest growing group of churches. ${ }^{7}$ A 2006 survey by the Pew Forum suggests that renewalists - including Pentecostals and charismatics - account for more than half of Kenya's population. ${ }^{8}$ The survey also shows that approximately $70 \%$ of Protestants in Kenya are either Pentecostal or charismatic, and about one third of Kenyan Catholics surveyed can be classified as charismatic.

The Pew Forum's estimates are further validated by newspaper reports that appear to support this immense growth. Alex Ndegwa, for example, reports that "the Registrar General's office is overwhelmed by increasing demands for church registration". 9 The former attorney general, Amos Wako, while speaking in a workshop for church leaders, revealed that the department was overwhelmed by increasing demand for registration of churches and that the facility was facing difficulties in processing 6,740 pending applications by various religious organisations. ${ }^{10}$ Wako also revealed that there were about

6 Pew Forum on Religion \& Public Life. 2011. Global Christianity - A Report on the Size and Distribution of the World's Christian Population, Washington, DC: Pew Research Center, December. Online at: http://www.pewforum.org/2011/12/19/ global-christianity-exec

7 Parsitau DS. 2011. “Arise, Oh Ye Daughters of Faith: Pentecostalism, Women and Public Culture in Kenya", in England H (ed). Christianity and Public Culture in Africa. Athens: Ohio University Press, 131-148.

8 As cited in Parsitau DS. 2014. Neo-Pentecostalism in Kenya: Its Civic and Public Role, PhD Diss, Kenyatta University.

9 Ndegwa A. 2007. "Over 6,000 Churches Awaiting Registration", The Standard, 4 September.

10 Ndegwa, “Over 6,000 Churches Awaiting Registration”. 
8,520 registered churches and that about 100 applications are filed every month. According to the Registrar of Societies, pastors and founding clergy register some churches as private properties co-owned with spouse and family, thereby making it personal property. This development partly explains the numerous protracted church ownership tussles that are rampant in the Kenyan courts, as well as a dramatic increase in scandals perpetuated by a section of NeoPentecostal clergy. ${ }^{11}$ Although not all of these churches seeking registration have Pentecostal and charismatic inclinations, most of them are of Pentecostal persuasion.

These different sets of statistics, while contested, nevertheless point to the tremendous growth of Neo-Pentecostal and charismatic churches in Kenya, many of which have sprung up in major urban centres, some within less than three to five kilometers apart. Some are huge churches with large membership while others are too small to be called churches. They nevertheless add to the numbers. These churches rose sharply to prominence due to a combination of factors. Scholars and Pentecostal leaders alike have linked this sudden growth of Pentecostalism in Africa with the economic crisis and stagnation of the 1980s and the subsequent Structural Adjustment Programmes (SAPs) that led to the worsening material conditions of life for many people during the 1980s and 1990s. ${ }^{12}$

In Kenya, as in many other African countries, religious actors are respected members of society. Religious actors are also increasingly asserting themselves in issues in public life, especially the political life of their countries. They do this through grassroots mobilisation, electioneering processes and peace building, contributing to national debates around constitutionalism and human rights issues, ${ }^{13}$ religious pluralism and interfaith dialogue, among others. Yet these countries also offer clear illustrations of how religious actors, particularly those

11 Although religious scandals are part and parcel of church history, the majority of scandals in the Kenyan religious scene affect mostly Pentecostal and charismatic clergy. This is based on my own personal observations as well as media reports on religious scandals in Kenya. See, for example, Shupe AD. 2008. Rogue Clerics: The Social Problem of Clergy Deviance. New Brunswick, NJ, and London: Transaction.

12 Parsitau DS. 2008. "The Impact of Structural Adjustments Programmes (SAPS) on the Health Status of Women in Kenya", in Sama M and Nguyen VK (eds). Governing Health Systems in Africa. Dakar: CODESRIA, 191-200.

13 A variety of Christian churches and faith-based organisations contributed to constitutional reforms in Kenya, while the Pentecostal and Evangelical churches sought to shape the 2010 Kenyan Constitution by vehemently opposing the inclusion of Muslim Kadhi Courts in the new constitution. For more on the Khadi Courts controversy in Kenya, see the essay of Hassan Juma Ndzovu, "Muslim and Christian contestation over the entrenchment of the Kadhi Courts in the Constitution of Kenya: Challenging the principle of a secular state" in this volume. See also Ndzovu HJ. 2014. Muslims in Kenyan Politics: Political Involvement, Marginalization, and Minority Status. Evanston, IL: Northwestern University Press, esp ch. 4; Green MC. 2013. "Religious and Legal Pluralism in Recent African Constitutional Reform", Journal of Law and Religion 28(2):401-439; Green MC. 2014. 
from Neo-Pentecostal Christianity are increasingly involved in moral, ethical and financial scandals.

Over the last one decade or so, religious scandals have proliferated in Kenya. There have been significant numbers of highly publicised cases of outright fraud on the part of some Pentecostal church clergy in the last five years or so. A growing number of clergy, mainly charlatans of Kenya's religious industry, have planted churches variously also called prophetic, deliverance and healing ministries to make money out of gullible members. As the religious industry and prophetic ministries have grown, there has also been a dramatic increase of religious scandals mainly associated though not limited to the Pentecostal and charismatic types.

Yet it is not by accidents that prophets and prophetesses have become an evergrowing feature of Africa's and Kenya's social and political landscape. The proliferation of prophets has made it difficult to tell the genuine ones from the charlatans, especially since there are thousands of gullible followers in need of spiritual guidance and prayers to surmount their daily existential challenges. In the course of ethnographic research carried over the last ten years, I found, for example, that some of these churches' reception desks have shelves full of "anointing oil," "anointing water" and "anointing salts" that are sold according to the nature of one's illness. The items also vary in price depending on the nature of illness. Serious illnesses such as cancer, HIV/AIDS, diabetes and high blood pressure require one to pay more for the anointed items than if one suffers from a cold or flu.

The selling of religious paraphernalia by these clergy to gullible members has only served to increase the vulnerability of those seeking spiritual solutions to their problems, while at the same time enriching some Pentecostal clergy and leading to intense scrutiny by both the print and electronic media, thereby exposing not just the scandals committed by clergy, who seem to exploit the vulnerabilities and gullibility of their followers, but also the gullibility and vulnerability of followers. Indeed, scandals committed by Kenyan leaders, whether religious or political or state agents, are so frequent that it can correctly be said that scandals are part of our daily lives.

\section{RELIGIOUS IMPUNITY AND THE FINANCIAL AND MORAL SCANDALS OF PENTECOSTAL CLERGY IN KENYA}

Although clerical scandals span the globe, relatively little attention has been given to understanding the scandals perpetrated by Pentecostal clergy, beyond abundant media scrutiny. In the course of writing this chapter, I found nearly no sociological literature on the scandals perpetrated by Pentecostal church clergy. This is interesting, considering religious scandals are not unique to Pentecostal

"From Social Hostility to Social Media: Religious Pluralism, Human Rights, and Democratic Reform in Africa", African Human Rights Law Journal 14(1):93-125. 


\section{Religion, Hate Speech, Diversity and Equality}

churches. For the present study, I draw on data accruing from intense media scrutiny and legal commentary on the churches, as well as my own personal observations and ethnographic studies. In this section, I explore selected case studies of recent religious scandals that have received significant attention in the Kenyan social and religious scene and led to calls to the government to regulate such churches.

\section{Prophet Victor Kanyari and Lucy Nduta of Salvation Healing Ministry}

In 2015, Victor Kanyari, a televangelist and pastor of the Salvation Healing Ministry, who is also the son of disgraced Prophetess Lucy Nduta, was exposed on Kenya Television Network's Jicho Pevu (Grim Eye), an investigative television series, ${ }^{14}$ for performing dubious miracles, faking healing and coaching his staff to tender phony testimonies of among other things, healing and prayer induced prosperity. The series exposed Kanyari for selling fake miracles and duping believers into giving money and other gifts to the church with the promise that God would look into their issues. Kanyari was further revealed to be a con artist, who preyed on his gullible followers for financial gains. This harrowing video exposé laced with shocking confessions from part of his team, revealed how this church founder obtained money from worshippers in the pretence that they would receive miracles.

The exposé of Makri ya Injili (prayer predators) clearly showed the deceptive methods that Salvation Healing Ministry's Victor Kanyari has used to lure and exploit his gullible and trusting followers for the past fifteen years in order to enrich himself. The exposé was supported by witness testimonies given by paid members of the church, who falsely testified that they had been miraculously healed of AIDS through Pastor Kanyari's prayers. Kanyari further washed the feet of his followers with water lased with potassium permanganate. When he did this, the water turned red and he told his followers that this was blood oozing out of their feet as he performed miracles of healing

In another exposé, Kanyari paid women, mostly prostitutes, to come for faith healing services with twisted mouths and faces which would miraculously be realigned during prayer services televised on the national Kenya Television Network. Kanyari was exposed not only as a con man and who used the services of prostitutes, but also as a drunk who cheated on his gospel musician wife in an act that ended their marriage. The story aired in KTN's prime time slot also showed footage in which Kanyari appeared to be falsifying phone calls on his radio programmes recorded from his house. Audiences were urged to send as much as 500,000 Kenyan shillings (\$5 000 US) after a single episode. Church members and anybody else who needed prayers had to send him a mandatory

14 Kanyari V. 2014. “Makriya Injili" [Prayer predators]. Ali M and Need AN (prod), Jicho Pevu [Grim Eye], Kenya Television Network (KTN), 2 November. 
310 Kenyan shillings (\$4 US) as a mandatory fee for prayer. This clip went viral, prompting government action to regulate these churches.

After the exposé, an unrepentant Kanyari bragged that he had become an instant celebrity, since he was the subject of discussion in Kenya's public and private discourses. He further bragged of his rise from a mere secondary school dropout and a former manual farm labourer to become a prophet whom everyone was talking about. He claimed that every church asks for seed offerings and tithes and all other manner of giving and that he was only fixed by the media which was a common practice in many Pentecostal and charismatic churches.

His mother, Prophetess Lucy Nduta, also of Salvation Healing Ministry and host of a weekly TV programme, was arrested in mid-2006 for extorting money from the faithful - particularly for requiring patients to plant a seed between 200,000 and 400,000 Kenyan shillings (\$2,000 to $\$ 4,000$ US) for her to cure them from AIDS through powerful prayers. Upon receipt of the payment, church elders would allegedly take the AIDS patients to a local AIDS clinic where they would be issued with false medical certificates giving them a clean bill of health. Evidently, many patients had sold their properties or borrowed money from friends and family to raise the seed money.

The prophetess argued that she had cured at least 200 AIDS cases in her church alone. According to religion scholar Paul Gifford, ${ }^{15}$ one woman had given a car worth 300,000 Kenyan shillings (\$3,000 US) for prayer for her ailing daughter, another nearly one million Kenyan shillings (\$10,000 US) for prayer to conceive and yet another 21,000 Kenyan shillings (\$210 US) to obtain a visa to the Netherlands. Another follower gave 20,000 Kenyan shillings (\$200 US) for a prayer to become rich. The prophetess tried to have the case dismissed, arguing that questions of faith and spirits did not fall within the court's competence. Instead, her plea was rejected and she was jailed for two years. It seems the son learnt from his mother and may have continued to run the church while his mother was serving her sentence.

The story of Victor Kanyari caused significant public outrage, with many calling for his arrest and prosecution, as well as the regulation of churches by the government. Kenyans across all social platforms took to Twitter, Facebook, WhatsApp and Instagram social media platforms to protest, because they were angry at the foolishness of the flock and the clergy taking advantage to fleece their gullible members. Although led to public conversation about the need to regulate the activities of Pentecostal churches, there appears to be a lack of consensus about the actions to take against the clergy.

While many on social media called for prosecution and regulation of the churches, lay members in Kanyari's church continued to attend services. For his part, Kanyari told his followers that the media and his enemies are out to finish him. Kanyari's reasoning not only blamed the work of devil for his misgivings

15 See Gifford P. 2009. Christianity, Politics and Public Life in Kenya. London: Hurst \& Co. 


\section{Religion, Hate Speech, Diversity and Equality}

instead of taking personal responsibility, but also served to defuse the story, which was likely the main objective. While a handful of Kanyari's followers left his church after the exposé, others stayed, convinced that the scandal was stage managed and orchestrated to malign the good name of the man of God, their beloved pastor. Nearly two years after the scandal, Kanyari walks around free, drives a top of the range Land Rover Sport and owns a palatial home on the outskirts of Nairobi. More importantly, he continues to preach every week in his church and attracts a modest congregation.

Following this exposé, the Director of Public Prosecution ordered an investigation of the activities of this church and its founder. Kanyari argued that he did not cheat or dupe anyone. Instead, they were willing members who paid for fake miracles and were not forced to but did it out of their own free will. Social media remained awash with mockery of the clergy and gullible members. Nevertheless, after a couple of weeks, the story died and Kanyari was back to business as usual.

\section{Apostle James Maina Ng'ang'a of Neno Evangelism Ministries}

Apostle James Maina Ng'ang'a of Neno Evangelism Ministries, a former convict turned televangelist, is a notorious man who runs one of the largest deliverance church ministries in Kenya. Neno Evangelism is largely a deliverance and healing ministry based in Nairobi, with branches spread across major towns in the country. James Maina Ng'ang'a was born in 1954, to a poor family that was not able to give him a stable upbringing or an education. Ng'ang'a moved to Nairobi in 1970 in search of some livelihood and found a job as a house servant.

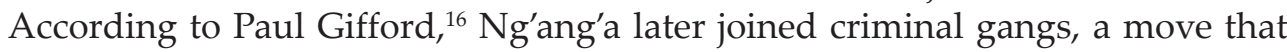
led to drugs, alcohol and a spiral of crime and many arrests and jail terms. He became a hard-core criminal and served many sentences in prison, during which time he was converted to the faith.

Ng'ang'a founded his Neno Evangelism Ministry, in 1992. In 1997, he opened his Neno Evangelism Centre situated at a central crossroads in one of Nairobi's best locations. His church services have attracted nearly 5,000 to 10,000 followers to his monthly crusades, which have since diminished. Ng'ang'a operates a Bible school, and has had a television programme on Kenya Broadcasting Corporation (KCB) every Saturday morning. He is immensely proud of his deliverance sessions and lays great emphasis on the gospel of prosperity. Thanks to his prosperity gospel, Ng'ang'a himself has grown immensely wealthy. In 2007, his manager estimated his wealth at a modest 100 million Kenyan shillings, according to Gifford. His lavish lifestyle reveals a story of a man who grew from rags to riches thanks to the activities of his church. ${ }^{17}$ Yet, Ng'ang'a is increasingly

16 Gifford, Christianity, Politics and Public Life in Kenya, 193.

17 Wesangula D. 2015. "Apostle James Maina Ng'ang'a: Wealthy man of God with a baffling past", The Standard, 9 August. Ng'ang'a past belies a poverty-stricken childhood and several jail terms for theft and other misdemeanours. 
arrogant, careless and flashy and loves to court attention and controversy with a careless abandon.

In 2012, a local radio station reported that a drunk Ng'ang'a got into a fight with his second wife and a security guard. His wife alleged in court papers that Ng'ang'a was not only a drunk, but also an adulterous and abusive husband and father. He walks around with a gun and has on many occasions been photographed drunk and rowdy. In early 2016, Ng'ang'a was driving drunk along the Naivasha-Nakuru highway and caused an accident that killed a middle-aged woman and seriously injured her husband. Ng'ang'a quickly left the scene of the accident and a young man appeared and claimed that he was the one driving the red Range Rover Sport. Apostle Ng'ang'a was aided by the police to run away from the scene of the accident, with the police commissioner coming out to defend the man of God. But eyewitnesses had identified a drunk Ng'ang'a and taken pictures of him at the scene of the crime.

This kind of impunity has elicited tremendous public outrage, especially when he colluded with the police to cover up the crime and bring in an impostor, who was paid 300,000 Kenyan shillings (\$3,000 US) to falsely state that he was the one driving the vehicle. Eyewitnesses reported that he was driving drunk and recklessly and therefore endangering the lives of other motorists. Ng'ang'a denied the claim through his lawyer. The incident was captured on WhatsApp and widely circulated on social media. When the exposé was aired, there was tremendous public outcry to tame rogue clergy. Social media went ablaze with accusations that the pastor had bribed policemen to release his dented Range Rover after a hit-and-run accidents. It was the action of Kenyans on social media that ultimately saw him arrested and charged in a court of law. After a short public outrage and intense media scrutiny, his case, like that of Kanyari went silent. Today Ng'ang'a continues to run and preach in his church every Sunday as if nothing happened, and many of his followers still patronise his church in search for miracles and deliverance.

\section{Gilbert Deya Ministries International (United Kingdom)}

Another much publicised case of outright fraud involving rogue clergy is that of U.K.-based but Kenyan-born Archbishop Gilbert Deya, who claims to have 36,000 followers in Great Britain. Deya established the Gilbert Deya Ministries International in 1997. According to biographical data on his church website, ${ }^{18}$ the ministry has church branches in Liverpool, London, Birmingham, Nottingham, Lutton, Reading, Manchester and Sheffield. His church is further claimed to be the fastest growing church in the U.K. and worldwide.

Gilbert Juma Deya is a fugitive wanted by Kenyan authorities for childtrafficking. His organisation claims that Deya is able to help infertile, postmenopausal women to conceive through the power of the Holy Spirit and

18 Gifford, Christianity, Politics and Public Life in Kenya, 157. 


\section{Religion, Hate Speech, Diversity and Equality}

special prayers. In the U.K., one woman claimed to have had three children in less than a year. Allegedly, he would pray for childless and post-menopausal women in London to exorcise the spirits keeping them childless. These women would then travel to Kenya and there deliver miracle babies in slum clinics. They would then take their new born babies back to Britain.

These outrageous claims turned out to be a child-trafficking racket. In 2004, Deya was arrested on charges of kidnapping and trafficking of children. Deya's wife Mary Deya was arrested in Kenya in September 2004 on charges of kidnapping a baby from Nairobi's Kenyatta Hospital. She denied the allegations, claiming she had given birth to the baby herself, although doctors proved that she could not have been the mother. Investigations led to a racket in which twenty-one babies were found in a house operated by these child traffickers. The kids were then placed into foster care in Kenya, after DNA tests found that none of the children were biologically related to the women they claimed to be the biological mothers. Rose Atieno Kiseren, a former pastor with Deya's ministry, was jailed for child-trafficking alongside Mary Deya. ${ }^{19}$ Upon her release from jail, Kiseren confessed that miracle babies were a hoax created by the Deyas and their accomplices to deceive her and other God-fearing people. The case dragged on with some of the documentation from the national hospital going missing, witnesses failing to appear and the judge of a new trial admitted she did not understand the delays. In May 2006, Mrs Deya was eventually jailed for two years for child abduction.

Bishop Deya continued to protest his innocence, claiming the miracles which God performed through him are of God and are beyond human understanding and that no man can explain them except God. According to Kenyan police, the ministry is a baby-snatching ring; thus, the authorities have frozen Deya's ministry's accounts, issued a warrant for his arrest in Kenya and petitioned for his extradition from the U.K. Deya is currently fighting extradition and seeking political asylum from his base in Glasgow. He is said to own three homes, as well as a jet and helicopter. He fought deportation from the U.K. to Kenya, but his ministry's accounts were frozen nevertheless.

\section{Allan and Kathy Kiuna of Jubilee Christian Centre (JCC)}

Allan and Kathy Kiuna are the founders of Jubilee Christian Centre (JCC) a sleek Neo-Pentecostal church situated in leafy Parklands in Nairobi. This church is modelled on the and is run on corporate principles, like a firm or a blue-chip company. This type of corporate church is complete with a separate administrative arm, a ministry arm and an investment arm - all to further the spread of the Gospel. Bishop Allan Kiuna and his wife Pastor Kathy Kiuna of the Jubilee Christian Centre (JCC) often use "marketplace rhetoric" to teach their flock how to succeed at the work place and how to grow wealthy.

19 Gifford, Christianity, Politics and Public Life in Kenya, 157. 
The Kiunas live an opulent life in the leafy suburb of Runda in Nairobi and are celebrated as Nairobi's most romantic couple, often appearing on TV to give tips on marriage and relationships. Kathy Kiuna runs the Women Without Limits programme, a pseudo-empowerment programme that is televised on Nation Television (NTV) as a forum where women open up about their day-to-day challenges and how they overcame them, thanks to the prayers and spiritual mentorship of the Kiunas. ${ }^{20}$ Kathy Kiuna courts controversy and loves media attention, appearing in all kinds of magazines and social media. The Kiunas unashamedly preach and promote the gospel of prosperity. Asked if their church is a prosperity gospel, Kathy Kiuna maintains: "We serve a prosperity God, Kathy counters. God wants us to be prosperous in every single way. His desire for us is to walk in abundance. I am praying for church people to show the likes of Bill Gates dust!" 21 Recently pictures of their houses circulated on social media, followed by outraged comments that pastors who serve God should not live extravagant lives. Kathy Kiuna has no apologies, stating: "Those who talk only know the 'after' they should have seen the 'before' To appreciate the work of God. She says. He has raised us up in the church and the church is as good as its flock-if the flock is walking in poverty so will the church." 22

The latest controversy surrounding the Kiunas was when they announced that the JCC church members had bought Bishop Allan Kiuna a private jet valued at two billion Kenyan shillings (\$20 million US) for his birthday. Pictures of the jet published on social media platforms went viral, with many criticising gullible members of prosperity churches, who are eager to feed the opulent lives of prosperity preachers at their own expense and suffering, continuing to live in poverty and want as their clergy grow into billionaires. Kathy and her husband are often pictured playing golf, on holiday in exotic places, and their sleek and expensive cars and sport motorbikes have also caused quite a stir. As with the churches mentioned above, criticism does not appear to lead to pragmatic discussions and national debates that might lead to tangible action. While those who are not overtly religious and can see through the teachings of these churches, thousands of followers turn to such clerics for prayers and spiritual leadership.

\section{TAMING THE BEAST: THE GOVERNMENT AND REGULATION OF RELIGIOUS ORGANISATIONS}

While the cases highlighted above are the most high-profile and controversial cases in Kenya, there are many other such controversies that do not receive

20 Deacon G and Parsitau D. 2016. “Empowered to Submit: Pentecostal Women in Nairobi Navigation Culture", Journal of Religion and Society 19:1-17.

21 Kiuna K. 2011. "Pastor Kathy Kiuna - On her Critics, Marriage, Divorce, Faith and being herself", True Love, November:45-47.

22 Kiuna, "On her Critics, Marriage, Divorce, Faith and being herself". See also Ondieki E. 2016. "Keeping up with the Kiunas and their jet-setting lifestyle", The Daily Nation, 17 December. 


\section{Religion, Hate Speech, Diversity and Equality}

media attention, and the phenomenon of rogue clergy is evident in many other parts of Africa. In Kenya, following the high-profile exposés of the rogue clergy described above, there was widespread public outrage on traditional and social media platforms. The Kenyan government reacted to these stories by imposing an indefinite suspension of registration of new religious and called for fresh registration of existing ones. This suspension was recently lifted after the President of Kenya, Uhuru Kenyatta, declared the ban over. ${ }^{23}$ Existing religious bodies were also required to file details of their status and financial returns with the Registrar of Societies.

The Attorney General of Kenya, Githu Muigai, immediately announced that a new framework was in the making to review the Societies Act and establish a special unit to manage religious institutions so that they can operate like trade unions and political parties. In publishing the new framework, Muigai, who has been critical of some of the religious organisations' activities, sought to bring sanity, transparency and accountability to the booming religious sector and reign on rogue clergy. The Religious Societies Compliance Rules, as the framework is called, would define standards for religious institutions as well as local and foreign clergy. For example, in order to become a member of the clergy, an individual would have to obtain a certificate of good conduct from the police and clearance from the Ethics and Anti-Corruption Commission (EACC), while foreign clergy would have work permits and recommendation from their diplomatic missions.

At the organisational level, he government would also be given details, such as the names and locations of committee members and registered trustees of religious institutions. Similarly, religious societies would need to file annual returns of their exemption or non-exemption certificates or they would have their licences revoked. Religious institutions have in the past been registered as charities under the Societies Act. The term "society", in this case, refers to any club, company, partnership or other associations of ten or more persons whatever its nature or objective, established in Kenya or having its headquarters or chief place of business in Kenya and any branch of a society. The looseness of this term has empowered anyone to register an institution and make it a church. Yet for some time now, a section of the Kenyan public has wanted to see a stricter regulation of the churches, especially the newer Pentecostal churches and its leadership.

The proposed rules would have the clergy hold a theological certificate from an accredited theological institution. It is important to note that most of the rogue clergy mentioned above are self-imposed and self-proclaimed and have no known theological training. Instead they claim to have been called and anointed by God to start their churches or ministries. The new rules will affect all faiths, including mainstream churches, mosques and temples. The Kenyan government has additionally proposed a raft of tough new measures aimed

23 Mwangi W. 2017. "Uhuru lifts ban on church registration, warns against illegal activities", The Star, 12 March. 
at radically changing the way religious organisations conduct their business. The new draft rules published by the Attorney General Muigai aim at curbing religious societies that swindle Kenyans and engage in money-laundering, promote terrorism or become a public nuisance.

The rules have drawn sharp reactions from clergy from across the religious sector. A section of the clergy from across various denominational divides fought tooth and nail against these proposed regulations and threatened to vote out the government. They condemned Attorney General Muigai for not consulting them, and it became a political issue. Clergy are very powerful in Kenya and the state does not like to rattle the clerics. The National Council of Churches of Kenya (NCCK) under its current general secretary Canon Peter Karanja cautioned against generalisation and treatment of all churches in the country as law breakers based on action of a few individuals. Ideally, mainline churches in Kenya are structured institutions with system of control. It is however a free-fall for Pentecostal church where democracy of the spirit.

Yet the action or inaction of the government in regulating religious organisation and rogue clergy points to a number of tensions and paradoxes for the Kenyan government. This is because the Kenyan Constitution 2010, Article 32(1) states that every person has the right to freedom of conscience, religion, thought, belief and opinion. Article 32(2) further states that every person has a right to either individually or in community with others in public or in private to manifest any religion or belief through worship, practice, teaching or observance of a day of worship. It is this legal and policy framework that religious clergy have exploited to make sure that they are not held to account.

At the same time, religion is a strong social and political force in Kenya because of its capacity for mobilisation. In Kenya, religion and politics often flows into each other. The church is co-opted by the state and vice versa. When churches feel threatened by the state, they often threaten to mobilise their religious constituencies to vote out the government. This is because, firstly, they enjoy good patronage and have capacities to easily unite different social groups, secondly, have strong national and international links, and thirdly, they enjoy global solidarity, like as witnessed during the 2010 constitutional review process, in which U.S.-aligned Evangelicals supported Pentecostal churches that opposed the passage of the new constitution.

\section{PROPHETS FOR PROFITS OR JUST GULLIBLE MEMBERS! : A MORAL AND ETHICAL CRITIQUE OF NEO-PENTECOSTAL CHURCH CLERGY}

Africa is faced with tremendous social, economic and political challenges, as well as a moral and leadership crisis. In fact, since the infamous Structural Adjustments Programmes (SAPs) of the 1970s and 1980s, ${ }^{24}$ African nations have

24 See Deacon and Parsitau, "Empowered to Submit: Pentecostal Women in Nairobi Navigation Culture"; Parsitau, "The Impact of Structural Adjustments Programmes (SAPS) on the Health Status of Women in Kenya". 
faced numerous challenges, including unemployment, increased poverty and collapse of infrastructure, particularly in healthcare and education, that have put tremendous strains on service delivery. Coupled with the lack of social welfare, increased corruption and ethnic tensions, there has been resource-based and politically inspired conflict leading to insecurity, as well as acts of terrorism leading to mass displacement and thousands of refugees, that have produced a total collapse of social structures. The impact of the SAPs was felt across the African continent, but it also coincided with the proliferation of Pentecostal and charismatic churches, which many observers have directly linked to the SAP crisis. ${ }^{25}$ Many poor and vulnerable people turned to deliverance and faith healing ministries to cater to their daily existential problems and dull their sufferings.

Since then, Pentecostalism has become a thriving business and the shortest route to wealth and influence on a continent teaming with population, unemployment, poverty and disease, conflict, environmental degradation. Local pastors employ all sorts of tricks and techniques to exhort money from gullible folks. They use this money to build magnificent churches, buy luxurious cars, houses and aircrafts and live openly opulent lives, while their church members languish in poverty, misery and squalor. In most cases, pastors tell the faithful to give money to God, so that God will bless them in return. They dupe people by telling them that divine favours come to those who pay their tithes and offerings regularly. Often, they use biblical injunctions such as "givers never lack" to squeeze money out of people.

Pentecostal pastors also claim they have power to make the deaf hear, the blind see and the lame walk, as in the case of Archbishop Deya discussed above. There have been indiscriminate claims of miracles and divine healing from Pentecostal clergy, in a context of crippled medical facilities often plagued by lack of medicine, medical facilities and equipment, striking health personnel, corruption and the politics of healthcare that exist in many other African countries. This has led to increased suffering for the impoverished masses who cannot afford proper medical care. Amidst this desperation, unscrupulous clergy take advantage of the African healthcare predicament or to total absence of it. Such clergy are cashing on the desperation and gullibility of Africans by offering ineffective prayers and healing crusades to promote and enrich themselves. The healthcare crisis in Africa breeds desperation and foments the desire for miracles, faith healing and deliverance sessions to dull the pain and desperation of the sick and poor.

There is a tendency for many in this sector to claim the ability to cure AIDS, cancers, disabilities, prophesy of impending disasters, conflicts, death and all manner of diseases and conditions. At prayer healing services in some Pentecostal churches, pastors invite people infected with HIV to come forward for public healing prayers after which they burn their anti-retroviral medications

25 Gifford, Christianity, Politics and Public Life in Kenya, 2009. 
and declare the persons healed. The cure is not free, and many spend a fortune to procure it. The controversial prayers continue even as believers' conditions worsen and some die. The situation has even spawned debates over whether science or religion should take the lead in the fight against the AIDS pandemic. Desperation, stigma, family rejection, fears of witchcraft and all other social anxieties drive people into a never-ending search for miracles and cures found in the myriads of healing crusades and prayer rallies. This is particularly worrying and frustrating for people infected with HIV, but more importantly alarming for health practitioners working in the health sector, as this negates the achievement against the HIV/AIDS pandemic.

While Pentecostalism has developed over the years, criticism has also grown, along with the accusation that pastors deceived churchgoers to get rich. At the same time, the growing rise of political power among Pentecostals also makes them untouchable. Many are political actors shaping debates and driving policy. Anyone who is critical of Pentecostal pastors is likely to come across strong opposition, resistance, and condemnation from enthusiastic members and in some cases politicians and governments. For example, when the attorney general published a proposed the aforementioned regulatory framework to control rogue clergy and religious organisations in Kenya, the opposition party, led by the former prime minister criticised the government for unfairly targeting religious institutions based on a few rotten apples.

Even though opposition to certain scandals draw general condemnation from across the board, many people still felt that the religious sector should not be regulated. Yet there is also growing criticism from a significant minority who are gaining voice in social media platforms and want to see religious organisations held to account. For example, Kenyans on social media platforms have criticised Kenyan clergy's activities that are deemed inappropriate. Over time, media and public scrutiny may create a more critical imagination among adherents, who will begin to question their leaders and churches, but the exploitation persists in the short term.

Are Kenyan and by extension African Christians gullible or just desperate? There is a huge section of followers who fall into these categories. These followers are searching for a moral vocabulary in grappling with hard social and economic times. This is what makes them gullible. For many, church is a space to be in community with one another - a space for healing both physical and emotional and spiritual pain and for negotiating relationships and identities. People's involvement in these churches cannot be neatly associated with any particular issues. Instead, it involves complexity of issues that are not just spiritual but are also personal, and communal. During times of crisis, people go to church to be in community.

In Africa, many people are perpetually living in moments of one crisis after another. They feel lost, alone and in need of moral guidance. They look up to their clergy to provide a moral universe and leadership and space for healing. 
At the same time, some rogue clergy have taken advantage of this situation, and many attempt to speak the language that the gullible want to hear. This is a huge challenge that many African governments grapple with on a daily basis. It is for such reasons that in 2004, the Nigerian Broadcasting Commission banned the broadcast of miracles on national television. Faith healing is the greatest threat to scientific medicine and healthcare delivery in Africa. Miracles have no basis in science, reason and common sense. Claims of divine cure and healing cannot be reconciled with the dire health situation in many African countries.

The greatest threat to Pentecostalism is its unregulated clergy and the moral failure of its leadership. Although other Christian movements have suffered, Pentecostalism seems particularly rife. Deeply embedded within Pentecostalism's ethos is a cult of personality. Charismatic leaders are put on a pedestal of accountability and often virtually worshipped by many of their followers. At the same time, many are averse to education, especially theological education, instead privileging the power of the Holy Spirit as their sole teacher. However, clergy are powerful and command tremendous respect. You can't touch the church. Laws to regulate the churches are fiercely opposed by the churches themselves, who form a huge voting block. It is particularly difficult in a largely Christian nation.

Thirdly, too many Pentecostal clergy handle church money as personal money and church properties as family business. They travel alone, without having to account for their whereabouts or activities. While many Pentecostal churches such as CITAM have instituted structures and policies to handle cases of pastoral misconduct, ineptitude and financial misconduct and impropriety, many find these policies hard to enforce. In Kenya, Pentecostal and charismatic churches are under the Evangelical Alliance of Kenya, but it is not clear how they handle these issues. There is no body that regulates independent churches in Kenya, and a favourite Pentecostal saying, "touch not my anointed" (Psalms 105:15), is used to forbid or stifle criticism of the movements' leaders.

Sexual promiscuity and financial misconduct are rife and rampant within church ranks and little is done about it unless a scandal becomes public. Yet, Pentecostals tend to be forgiving of their clergy's moral lapses both in Kenya and beyond. Kanyari and Ng'ang'ga are back to preaching. They are a power unto themselves. This has tarnished many Pentecostal churches image and standing in society. Since then, the churches in Kenya have struggled to gain respect, but they also appear to struggle with an identity crisis. Many have decried bad religion in Kenya as the churches continue to grapple with rogue clergy and bad religion, prompting observers to ask if religion is indeed the bane of the Kenyan society. This has attracted a lot of attention to the clergy, their sources of wealth and their morals. Pentecostal clergy's moral and ethical failures are reflective of the general leadership crisis prevalent in much of Sub-Saharan Africa. Corruption is rife in many African nations and integrity of leadership in government, the private sector as well as the religious sector 
is lacking. Corruption is prevalent in many African countries, including the most religious countries. Kenya and Nigeria, for example, are highly religious countries, but they are also some of the most corrupt countries in the world. This is the paradox that needs further attention. The same scenario is replicated in other countries such as Zimbabwe, South Africa and Uganda. The church leadership is critical in fighting social, economic and political ills, such as corruption, ethnicity, insecurity and lack of good governance. Yet a corrupt church cannot fight these ills when it has itself been co-opted by the state. Instead, the case for rogue clergy is a reflection of the general state of the nation of Kenya, where social, economic and political scandals are part of the country's social and political landscape.

\section{CONCLUSION}

In the recent past, Kenyans have witnessed an increasingly high number of religious scandals committed by the so-called men and women of God, who are supposedly also the keepers of morality and ethics. Yet, rogue clergy are increasingly becoming a panacea to the Kenyan public, and there has been significant pressure for the government to tame rogue clergy by introducing regulations to tame the religious industry. At the same time, questions are being raised about the gullibility of Kenya's faithful, who appear to learn a lesson or two from rogue clergy to whom they continue to fall prey. This chapter has attempted to highlight these tensions by focusing on the challenges this presents to the public and to the Kenyan government caught up between protecting freedoms of expression and attempting to regulate religious organisations and rogue clergy in Kenya. The government must protect gullible members from rogue clergy whose sole aim is to enrich themselves at the expense of vulnerable and desperate souls whose only hope seems to be supernatural. The government must engage with faith-based organisations, sensitise the public and find a lasting solution to the problem. Faith-based organisations themselves should also devise internal mechanism to regulate themselves, if they hope to reclaim their integrity and respect. 